\title{
Article \\ Electrodeposition of Aluminum in the 1-Ethyl-3-Methylimidazolium Tetrachloroaluminate Ionic Liquid
}

\author{
Meng Shi ${ }^{1}$, Junhua Jiang ${ }^{2, *}$ and Haiyan Zhao ${ }^{1, *}$ \\ 1 Department of Chemical and Biological Engineering, University of Idaho, Idaho Falls, ID 83401, USA; \\ shi7608@vandals.uidaho.edu \\ 2 Nuclear Science and Technology Directorate, Idaho National Laboratory, Idaho Falls, ID 83415, USA \\ * Correspondence: junhua.jiang@inl.gov (J.J.); haiyanz@uidaho.edu (H.Z.)
}

Citation: Shi, M.; Jiang, J.; Zhao, $\mathrm{H}$. Electrodeposition of Aluminum in the 1-Ethyl-3-Methylimidazolium Tetrachloroaluminate Ionic Liquid. Electrochem 2021, 2, 185-196. https://doi.org/10.3390/

electrochem 2020013

Academic Editor: Masato Sone

Received: 8 March 2021

Accepted: 24 March 2021

Published: 26 March 2021

Publisher's Note: MDPI stays neutral with regard to jurisdictional claims in published maps and institutional affiliations.

Copyright: (c) 2021 by the authors. Licensee MDPI, Basel, Switzerland. This article is an open access article distributed under the terms and conditions of the Creative Commons Attribution (CC BY) license (https:/ / creativecommons.org/licenses/by/ $4.0 /)$.

\begin{abstract}
The electrodeposition of Al was investigated in an ionic liquid (IL), with 1-ethyl-3methylimidazolium tetrachloroaluminate $\left([\mathrm{EMIm}] \mathrm{AlCl}_{4}\right)$ as the electrolyte with $\mathrm{AlCl}_{3}$ precursor. The [EMIm] $\mathrm{AlCl}_{4}$ electrolyte exhibited a wide and stable electrochemical window from 3.2 to $2.3 \mathrm{~V}$ on a glassy carbon electrode when temperature was increased from $30^{\circ} \mathrm{C}$ to $110{ }^{\circ} \mathrm{C}$. The addition of $\mathrm{AlCl}_{3}$ into [EMIm] $\mathrm{AlCl}_{4}$ generated significant well-developed nucleation growth loops, and new coupled reduction and oxidation peaks in cyclic voltammograms corresponding to the $\mathrm{Al}$ deposition and dissolution, respectively. A calculation model was proposed predicting compositions of anions in $\mathrm{AlCl}_{3} /[\mathrm{EMIm}] \mathrm{AlCl}_{4}$ system, and $\left[\mathrm{Al}_{2} \mathrm{Cl}_{7}\right]^{-}$was found to be the active species for $\mathrm{Al}$ deposition. In $\mathrm{AlCl}_{3} /[\mathrm{EMIm}] \mathrm{AlCl}_{4}$ (1:5), the reduction rate constants were $1.18 \times 10^{-5} \mathrm{~cm} \mathrm{~s}^{-1}$ and $3.37 \times 10^{-4} \mathrm{~cm} \mathrm{~s}^{-1}$ at $30^{\circ} \mathrm{C}$ and $110^{\circ} \mathrm{C}$, respectively. Scanning electron microscope (SEM), energy dispersive spectroscope (EDS), and X-ray diffraction (XRD) microscope results showed that the metallic $\mathrm{Al}$ film had been successfully deposited on glassy carbon electrodes through constant-potential cathodic reductions. The $[\mathrm{EMIm}] \mathrm{AlCl}_{4}$ was a promising electrolyte directly used for $\mathrm{Al}$ deposition.
\end{abstract}

Keywords: electrodeposition; aluminum; ionic liquids; imidazolium tetrachloroaluminate; aluminum chloride

\section{Introduction}

Al materials and coatings have been extensively investigated in electronic and automotive industries due to their excellent conductivity, corrosion resistance, and wear tolerance [1,2]. Al can be electrochemically deposited from ionic liquids with an aluminum salt precursor, due to the wide electrochemical window of ionic liquids. The deposits were affected by factors, such as the substrate materials [3], composition of the mixture $\left(\mathrm{AlCl}_{3}\right.$-to-IL ratio) [4-6], operating temperature [7-10], deposition current density $[9,11]$, substrate pretreatment [11], stirring [7,8,12], and additives [7,13].

The $\mathrm{AlCl}_{3}$-to-IL ratio determines the distribution of various $\mathrm{Al}$ anion species and viscosity of the system, which controls reaction kinetics and diffusion process for $\mathrm{Al}$ deposition. The $\mathrm{AlCl}_{3} /[\mathrm{BMIm}] \mathrm{Cl}$ mixtures with 2:1 molar ratio resulted in a dull $\mathrm{Al}$ deposit whereas the 1.5:1 molar ratio mixture led to a bright $\mathrm{Al}$ surface because the $\mathrm{AlCl}_{3} /[\mathrm{BMIm}] \mathrm{Cl}$ at 1.5:1 is more viscous with less aluminum complex ions [4]. Al deposition is the direct result from electrochemical reduction of chloroaluminate complexes [14,15].

In general, the chloroacidity determines reactivity and electrochemistry in the ionic liquid electrolyte. The Al deposition chemistry is complicated because of the chemical nature of different chloroaluminate complexes species including chemical equilibria and interconversion $[16,17]$. The equilibrium composition was highly dependent on the amount of $\mathrm{AlCl}_{3}$ added to the ionic liquid. The main anions are $\left[\mathrm{AlCl}_{4}\right]^{-},\left[\mathrm{Al}_{2} \mathrm{Cl}_{7}\right]^{-}$, and $\mathrm{Cl}^{-}$in the alkylimidazolium chloride and $\mathrm{AlCl}_{3}$ solutions [18-20]. When $\mathrm{AlCl}_{3}$ concentration is high, 
more complicated anions such as $\left[\mathrm{Al}_{3} \mathrm{Cl}_{10}\right]^{-},\left[\mathrm{Al}_{4} \mathrm{Cl}_{13}\right]^{-}$, and $\left[\mathrm{Al}_{2} \mathrm{OCl}_{5}\right]^{-}$will be formed, which are confirmed by Infrared (IR) spectroscopy and the Nuclear Magnetic Resonance (NMR) spectroscopy [21].

Various ionic liquids have been investigated for $\mathrm{Al}$ deposition including 1-methyl-3ethylimidazolium chloride ([MEIm]Cl) [18-20,22-25], 1-ethyl-3-methylimidazolium chloride ([EMIm]Cl) [3,11,26-29], 1-butylpyrrolidine [30], 1-butyl-3-methylimidazolium chloride ([BMIm]Cl) [4,7-9,31], and 1-(2-methoxyethyl)-3-methylimidazolium chloride ([MoeMIm] $\mathrm{Cl}$ [32]. One class of ionic liquids, imidazolium-based tetrachloroaluminates, has much lower melting points than its chloride counterpart. These ionic liquid systems also received attention in battery applications [33]. Al metal was found as a deposit in an ethylimidazolium-contained system [33-37]. A representative of this class is 1-ethyl-3methylimidazolium tetrachloroaluminate $\left([\mathrm{EMIm}] \mathrm{AlCl}_{4}\right)$ with melting point of $9{ }^{\circ} \mathrm{C}$ while the melting point for its chloride counterpart [EMIm] $\mathrm{Cl}$ is at $77-79^{\circ} \mathrm{C}$. $[\mathrm{EMIm}] \mathrm{AlCl}_{4}$ can simplify the preparation process for electrochemical deposition with better control on mixing and heating. Furthermore, it is commercially available on industrial scale and makes $\mathrm{Al}$ deposition possible directly at lower temperatures. However, there is only some computational study available for exploring the unique physical properties of the tetrachloroaluminate systems recently [38,39]. However, due to the sensitivity of moisture and oxygen in the experimental performance in ionic liquids, the operations need to be conducted in protective atmosphere such as an inert gas environment. It makes the promotion and scale-up of the process difficult in larger scales [3,30]. The electrochemical characteristics of these systems have not received attention and their potential as a medium for the $\mathrm{Al}$ deposition has not been examined.

In this work, the electrochemical window of the $[\mathrm{EMIm}] \mathrm{AlCl}_{4}$ will be defined and thermodynamic models for $\mathrm{AlCl}_{3} / \mathrm{IL}$ systems at $30^{\circ} \mathrm{C}$ and $110{ }^{\circ} \mathrm{C}$ will be developed. By employing $\mathrm{AlCl}_{3} /[\mathrm{EMIm}] \mathrm{AlCl}_{4}$ as the electrolyte, electrodepositions will be carried out on glass carbon substrates in the open air, and the products will be characterized for the morphology, composition, and phase information. These results will be of academic and industrial interest in not only the development of metal deposition processes, but also employing the electrochemistry of the [EMIm] $\mathrm{AlCl}_{4}$ as a model system to deepen our understanding of the related process chemistry and electrode reactions.

\section{Experimental}

\subsection{Chemicals and Materials}

$\mathrm{AlCl}_{3}\left(99 \%\right.$, Alfa Aesar, Tewksbury, MA, USA) and [EMIm] $\mathrm{AlCl}_{4}\left(\mathrm{C}_{6} \mathrm{H}_{11} \mathrm{AlCl}_{4} \mathrm{~N}_{2} \geq\right.$ 95\%, Sigma Aldrich, St. Louis, MO, USA) were used for Al electrodepositions. [EMIm] $\mathrm{AlCl}_{4}$ is a light-yellow transparent liquid at room temperature. All chemicals were used as received. Glassy carbon disk electrodes were used as working electrode (GC, $1 \mathrm{~mm}$ diameter, eDAQ, Colorado Spring, CO, USA). Aluminum wires were used as counterelectrode and reference electrode (1 mm diameter, 99.9995\% metal basis, Alfa Aesar). Techne Dri-Block ${ }^{\circledR}$ Digital Block Heater was used for temperature control $\left( \pm 1^{\circ} \mathrm{C}\right)$. A $3 \mathrm{~mL}$ glass vial (eDAQ Inc. Colorado Spring, CO, USA) was used for electrodeposition cell. VersaSTAT 4 Potentiostat (Princeton Applied Research, Oak Ridge, TN, USA) with VersaStudio was used for all electrochemical measurements and data acquisition.

\subsection{Procedure and Methodology}

To determine the stability of [EMIm] $\mathrm{AlCl}_{4}$, cyclic voltammetry $(\mathrm{CV})$ was measured for [EMIm] $\mathrm{AlCl}_{4}$ in the three-electrode electrochemical cell at a series of temperatures including $30{ }^{\circ} \mathrm{C}, 50{ }^{\circ} \mathrm{C}, 70{ }^{\circ} \mathrm{C}, 90^{\circ} \mathrm{C}$, and $110{ }^{\circ} \mathrm{C}$ at a scan rate $100 \mathrm{mV} \mathrm{s}^{-1}$.

$\mathrm{AlCl}_{3} /[\mathrm{EMIm}] \mathrm{AlCl}_{4}$ mixtures were prepared by adding portion of $\mathrm{AlCl}_{3}$ powders into the $[\mathrm{EMIm}] \mathrm{AlCl}_{4}$ liquid at the room temperature and heated up to $110{ }^{\circ} \mathrm{C}$ for $2 \mathrm{~h}$ until homogeneity was reached. As the electrical conductivity for $\mathrm{AlCl}_{3} / \mathrm{IL}$ (exclusive of $\mathrm{Al}$ species) started to decrease when the ratio was higher than 1 [25], a small amount of $\mathrm{AlCl}_{3}$ was added and the final ionic liquid mixture was $\mathrm{AlCl}_{3} /[\mathrm{EMIm}] \mathrm{AlCl}_{4}$ at a molar 
ratio of 1:5. In order to determine the $\mathrm{Al}^{3+}$ reduction potential, $\mathrm{CVs}$ in $\mathrm{AlCl}_{3} /[\mathrm{EMIm}] \mathrm{AlCl}_{4}$ (1:5) were measured at various scan rates including $10,20,50,100$, and $150 \mathrm{mV} \mathrm{s}^{-1}$ at $30{ }^{\circ} \mathrm{C}$ and $110{ }^{\circ} \mathrm{C}$, respectively. The nucleation mechanism was studied by short-time chronoamperometry (CA) measurements. The current-time transients were measured by applying a series of constant cathodic potentials in the kinetic regime. After each currenttime transient measurement, a constant potential $1.0 \mathrm{~V}$ was applied on the glassy carbon disk working electrode for 5 min to clean the electrode surface and remove the Al layer on the working electrode. All potentials were reported versus the $\mathrm{Al}$ reference electrode.

The $\mathrm{Al}$ electrodepositions in $\mathrm{AlCl}_{3} /[\mathrm{EMIm}] \mathrm{AlCl}_{4}$ (1:5) were carried out by long-time CA measurements. The constant potential depositions were controlled a little higher than the $\mathrm{Al} / \mathrm{Al}^{3+}$ potential. A polished and clean $\mathrm{Al}$ wire working electrode was used for each deposition. The $\mathrm{Al}$ deposition samples were washed thoroughly in acetonitrile first and then acetone. The samples were left in air at room temperature for $24 \mathrm{~h}$ before any material characterization.

The Al deposition samples were analyzed using a JEOL JSM-6610LV scanning electron microscope (SEM, Apollo SDD X-Ray spectrometer, $20 \mathrm{kV}$ ) for morphology and elemental composition information. The X-ray diffraction (XRD) was performed for the Al deposits from $30^{\circ}$ to $90^{\circ}$ (2 theta) at $4^{\circ} \mathrm{min}^{-1}$ for phase identification (Rigaku SmartLab, $\mathrm{Cu} \mathrm{K} \alpha$ radiation, $\lambda=1.54056 \AA$, voltage $=40 \mathrm{kV}$ and current $=44 \mathrm{~mA}$ ).

\subsection{Chloroaluminate Complexes Distribution Calculation}

$\mathrm{Al}$ anions in the $\mathrm{AlCl}_{3} /[\mathrm{EMIm}] \mathrm{AlCl}_{4}$ solution included $\left[\mathrm{AlCl}_{4}\right]^{-},\left[\mathrm{Al}_{2} \mathrm{Cl}_{7}\right]^{-},\left[\mathrm{Al}_{3} \mathrm{Cl}_{10}\right]^{-}$, and $\left[\mathrm{Al}_{4} \mathrm{Cl}_{13}\right]^{-}$[18-20]. The distributions of the $\mathrm{Al}$ anions for $\mathrm{AlCl}_{3} /[\mathrm{EMIm}] \mathrm{AlCl}_{4}(1: 5)$ at $30{ }^{\circ} \mathrm{C}$ and $110{ }^{\circ} \mathrm{C}$ were calculated based on $K_{i}=\exp \left(\frac{-\Delta H_{i}{ }^{0}}{R T}+\frac{\Delta S_{i}{ }^{0}}{R}\right)$ using standard entropy and enthalpy (Table 1) [20]. The chloroaluminate species reached equilibrium in the ionic liquid as following reactions [18-20]:

$$
\begin{gathered}
{\left[\mathrm{AlCl}_{4}\right]^{-} \leftrightarrow 0.5 \mathrm{Al}_{2} \mathrm{Cl}_{6}+\mathrm{Cl}^{-}, \mathrm{K}_{1}=\frac{\left[\mathrm{Cl}^{-}\right]\left[\mathrm{Al}_{2} \mathrm{Cl}_{6}\right]^{0.5}}{\left[\left[\mathrm{AlCl}_{4}\right]^{-}\right]}} \\
{\left[\mathrm{Al}_{2} \mathrm{Cl}_{7}\right]^{-} \leftrightarrow 0.5 \mathrm{Al}_{2} \mathrm{Cl}_{6}+\left[\mathrm{AlCl}_{4}\right]^{-}, K_{2}=\frac{\left[\left[\mathrm{AlCl}_{4}\right]^{-}\right]\left[\mathrm{Al}_{2} \mathrm{Cl} l_{6}\right]^{0.5}}{\left.\left.\left[\mathrm{Al}_{2} \mathrm{Cl}\right]_{7}\right]^{-}\right]}} \\
{\left[\mathrm{Al}_{3} \mathrm{Cl}_{10}\right]^{-} \leftrightarrow 0.5 \mathrm{Al}_{2} \mathrm{Cl}_{6}+\left[\mathrm{Al}_{2} \mathrm{Cl}_{7}\right]^{-}, K_{3}=\frac{\left.\left[\left[\mathrm{Al}_{2} \mathrm{Cl}_{7}\right]^{-}\right]\left[\mathrm{Al}_{2} \mathrm{Cl}\right]_{6}\right]^{0.5}}{\left[\left[\mathrm{Al}_{3} \mathrm{Cl} l_{10}\right]^{-}\right]}} \\
{\left[\mathrm{Al}_{4} \mathrm{Cl}_{13}\right]^{-} \leftrightarrow 0.5 \mathrm{Al}_{2} \mathrm{Cl}_{6}+\left[\mathrm{Al}_{3} \mathrm{Cl}_{10}\right]^{-}, K_{4}=\frac{\left[\left[\mathrm{Al}_{3} \mathrm{Cl}_{10}\right]^{-}\right]\left[\mathrm{Al}_{2} \mathrm{Cl}_{6}\right]^{0.5}}{\left[\left[\mathrm{Al}_{4} \mathrm{Cl}_{13}\right]^{-}\right]}}
\end{gathered}
$$

\begin{tabular}{|c|c|c|c|c|}
\hline Reaction & ${ }^{*} \Delta \mathrm{H}^{0} / \mathrm{kJ} \mathrm{mol}{ }^{-1}$ & ${ }^{*} \Delta \mathrm{S}^{0} / \mathrm{J} \mathrm{mol}{ }^{-1} \mathrm{~K}^{-1}$ & $\mathrm{~K}\left(30^{\circ} \mathrm{C}\right)$ & $\mathrm{K}\left(110^{\circ} \mathrm{C}\right)$ \\
\hline 1 & 69.547 & -172.17 & $1.04 \times 10^{-21}$ & $3.32 \times 10^{-19}$ \\
\hline 2 & 40.940 & 37.89 & $8.34 \times 10^{-6}$ & $2.49 \times 10^{-4}$ \\
\hline 3 & 25.574 & 36.78 & $3.25 \times 10^{-3}$ & $2.71 \times 10^{-2}$ \\
\hline 4 & 25.704 & 47.90 & $1.18 \times 10^{-2}$ & $9.92 \times 10^{-2}$ \\
\hline
\end{tabular}

Table 1. Thermodynamic equilibrium parameters for $\mathrm{Al}_{2} \mathrm{Cl}_{6}$ equilibria reactions.

* The activity coefficient $\mathrm{\gamma Al}_{2} \mathrm{Cl}_{6}$ is 3 [20].

The total mole fraction for all species was unity:

$$
\chi_{\mathrm{Cl}^{-}}+\chi_{\left[\mathrm{AlCl}_{4}\right]^{-}}+\chi_{\left.\left[\mathrm{Al}_{2} \mathrm{Cl}\right]_{7}\right]^{-}}+\chi_{\left[\mathrm{Al}_{3} \mathrm{Cl}_{10}\right]^{-}}+\chi_{\left[\mathrm{Al}_{4} \mathrm{Cl}_{13}\right]^{-}}+\chi_{\mathrm{Al}_{2} \mathrm{Cl}_{6}}=1
$$

where $\chi_{i}$ was the modified Temkin ion fraction [40] for the species $i, \chi_{i}=\frac{n_{i}}{n_{T}}$, and $n_{T}$ was the total molar amount of anions: $n_{T}=n_{\mathrm{Cl}^{-}}+n_{\left[\mathrm{AlCl}_{4}\right]^{-}}+n_{\left[\mathrm{Al}_{2} \mathrm{Cl}_{7}\right]^{-}}+n_{\left[\mathrm{Al}_{3} \mathrm{Cl} \mathrm{l}_{10}\right]^{-}}+$ $n_{\left[\mathrm{Al}_{4} \mathrm{Cl}_{13}\right]^{-}}+n_{\mathrm{Al}_{2} \mathrm{Cl} l_{6}}$. 
In addition, the charge balance also met the equation:

$$
n_{[E M I m]^{+}}=n_{C l^{-}}+n_{\left[A l C l_{4}\right]^{-}}+n_{\left[\mathrm{Al}_{2} C l_{7}\right]^{-}}+n_{\left[\mathrm{Al}_{3} \mathrm{Cl} l_{10}\right]^{-}}+n_{\left[\mathrm{Al}_{4} \mathrm{Cl} l_{13}\right]^{-}}
$$

By assuming a complete dissociation of the $\mathrm{IL}$, it gave $n_{[E M I m]^{+}}=n_{I L}$.

The materials balance for $\mathrm{Al}$ species was

$$
n_{\mathrm{AlCl}_{3}} n_{\left[\mathrm{AlCl}_{4}\right]^{-}}+2 n_{\left.\left[\mathrm{Al}_{2} \mathrm{Cl}\right]_{7}\right]^{-}}+3 n_{\left[\mathrm{Al}_{3} \mathrm{Cl} l_{10}\right]^{-}}+4 n_{\left[\mathrm{Al}_{4} \mathrm{Cl} l_{3}\right]^{-}}+2 n_{\mathrm{Al}_{2} \mathrm{Cl} l_{6}}
$$

$\chi_{\mathrm{AlCl}_{3}}$ was introduced as the initial molar ratio of $\mathrm{AlCl}_{3}: \chi_{\mathrm{AlCl}_{3}}=\frac{n_{\mathrm{AlCl}_{3}}}{n_{\mathrm{AlCl}_{3}+n_{\mathrm{IL}}}}$.

Combining the mass balance equations and charge balance equation, the following equation was established:

$$
\chi_{\left[\mathrm{AlCl}_{4}\right]^{-}}+2 \chi_{\left.\left[\mathrm{Al}_{2} \mathrm{Cl}\right]_{7}\right]^{-}}+3 \chi_{\left[\mathrm{Al}_{3} \mathrm{Cl}_{10}\right]^{-}}+4 \chi_{\left[\mathrm{Al}_{4} \mathrm{Cl}_{13}\right]^{-}}+\chi_{\mathrm{Al}_{2} \mathrm{Cl} l_{6}} \frac{2-\chi_{\mathrm{AlCl}_{3}}}{1-\chi_{\mathrm{AlCl}}}=\frac{\chi_{\mathrm{AlCl}_{3}}}{1-\chi_{\mathrm{AlCl}_{3}}}
$$

Equations (1)-(8) were solved simultaneously using numerical method within EXCEL for $\chi_{\mathrm{AlCl}_{3}}$ in the range of 0 and 1 at interval 0.0001 .

\section{Results and Discussion}

\subsection{Stability Window of [EMIm] $\mathrm{AlCl}_{4}$ at Various Temperatures}

$\mathrm{CVs}$ in [EMIm] $\mathrm{AlCl}_{4}$ at different temperatures were measured to determine the stability window (Figure 1). The CVs displayed wide flat zones between the fast-growing oxidation and reduction currents. The onset potentials for oxidation-current growth were very close to $1.5 \mathrm{~V}$ which is the oxidation of chloride anions [41,42]. In contrast, the onset potentials for the reduction-current growth were strongly dependent on temperatures, characteristic of a positive shift with increasing temperatures. At the negative potential limits, the cathodic peaks were attributed to the reduction of imidazolium ring [41]. Based on the onset potential differences for the oxidation and reduction current growth, the electrochemical windows of [EMIm] $\mathrm{AlCl}_{4}$ on the GC electrode were determined. The potential windows decreased from 3.2 to $2.3 \mathrm{~V}$ as the temperature was increased from $30{ }^{\circ} \mathrm{C}$ to $110^{\circ} \mathrm{C}$. These results are consistent with literature data measured under similar conditions $[41,43]$. No oxidation peak was observed in the electrochemical windows in the $\mathrm{CVs}$ indicating that the $\mathrm{Al}$ anion $\left[\mathrm{AlCl}_{4}\right]^{-}$dissociated from $[\mathrm{EMIm}] \mathrm{AlCl}_{4}$ was a very stable Lewis neutral anion and could not lead to Al electrodeposition [44-46].

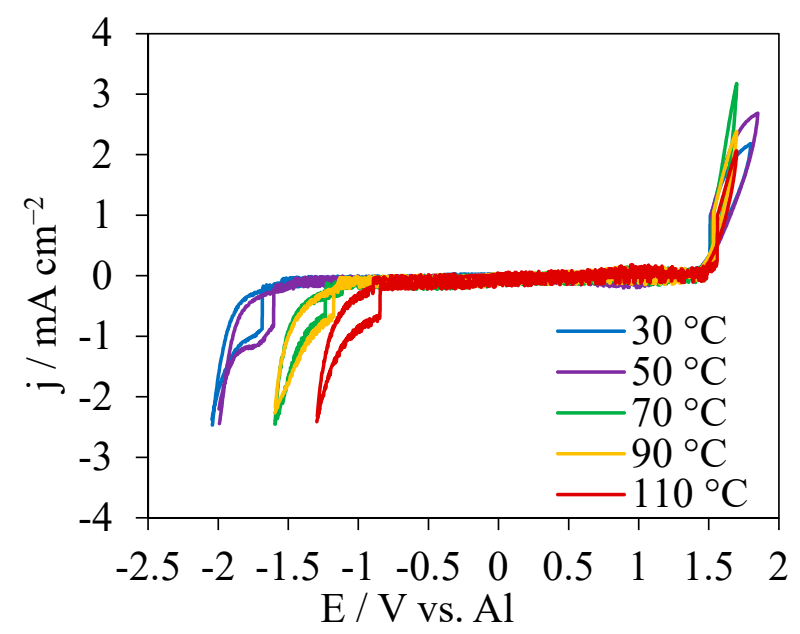

Figure 1. CVs in [EMIm] $\mathrm{AlCl}_{4}$ at $30{ }^{\circ} \mathrm{C}, 50{ }^{\circ} \mathrm{C}, 70{ }^{\circ} \mathrm{C}, 90^{\circ} \mathrm{C}$ and $110^{\circ} \mathrm{C}$ at a scan rate $100 \mathrm{mV} \mathrm{s}$. 


\subsection{Cyclic Voltammetry in $\mathrm{AlCl}_{3} /[\mathrm{EMIm}] \mathrm{AlCl}_{4}$ (1:5)}

The advantage of using the [EMIm] $\mathrm{AlCl}_{4}$ is mostly its simple operation. Though [EMIm] $\mathrm{AlCl}_{4}$ can be generated by mixing equimolar [EMIm] Cl and $\mathrm{AlCl}_{3}$, the mixing process requires heating to melt the $[\mathrm{EMIm}] \mathrm{Cl}$ and continuous stirring to release heat generated by the combination reaction [27]. In contrast, by using [EMIm] $\mathrm{AlCl}_{4}$, it is a liquid at the room temperature and the operation of mixing with $\mathrm{AlCl}_{3}$ does not need extra heating or stirring.

The CVs in $\mathrm{AlCl}_{3} /[\mathrm{EMIm}] \mathrm{AlCl}_{4}(1: 5)$ at $30{ }^{\circ} \mathrm{C}$ and $100{ }^{\circ} \mathrm{C}$ were shown in Figure 2a,b, respectively. At $30^{\circ} \mathrm{C}$, the onset potentials for $\mathrm{Al}$ deposition became higher from $-0.25 \mathrm{~V}$ to $-0.3 \mathrm{~V}$ as the scan rates increased from $10 \mathrm{mV} \mathrm{s}^{-1}$ to $150 \mathrm{mV} \mathrm{s}^{-1}$. At $110^{\circ} \mathrm{C}$, the onset potentials for $\mathrm{Al}$ deposition at different scan rates were concentrated at approximately $-0.14 \mathrm{~V}$, much lower than those in $\mathrm{CVs}$ at $30^{\circ} \mathrm{C}$. The potential range for $\mathrm{CVs}$ at $30^{\circ} \mathrm{C}$ was from OCP to $-0.9 \mathrm{~V}$, and the current intensity at $150 \mathrm{mV} \mathrm{s}^{-1}$ was responded at 12.5 to $-15.2 \mathrm{~mA} \mathrm{~cm}^{-2}$, the highest current range. For CVs at the same scan rate $150 \mathrm{mV} \mathrm{s}^{-1}$ at $110{ }^{\circ} \mathrm{C}$, the current response was much higher in a range of -63.8 to $87.2 \mathrm{~mA} \mathrm{~cm}{ }^{-2}$. At both temperatures, the re-oxidation charges were smaller than the reduction charges. At $30{ }^{\circ} \mathrm{C}$, the $\mathrm{Al}$ dissolution was around $26.5 \%$ to $36.4 \%$ of the charge used in the reduction reaction, compared with the proportion of $61.8 \%$ to $79.2 \%$ in CVs at $110{ }^{\circ} \mathrm{C}$.
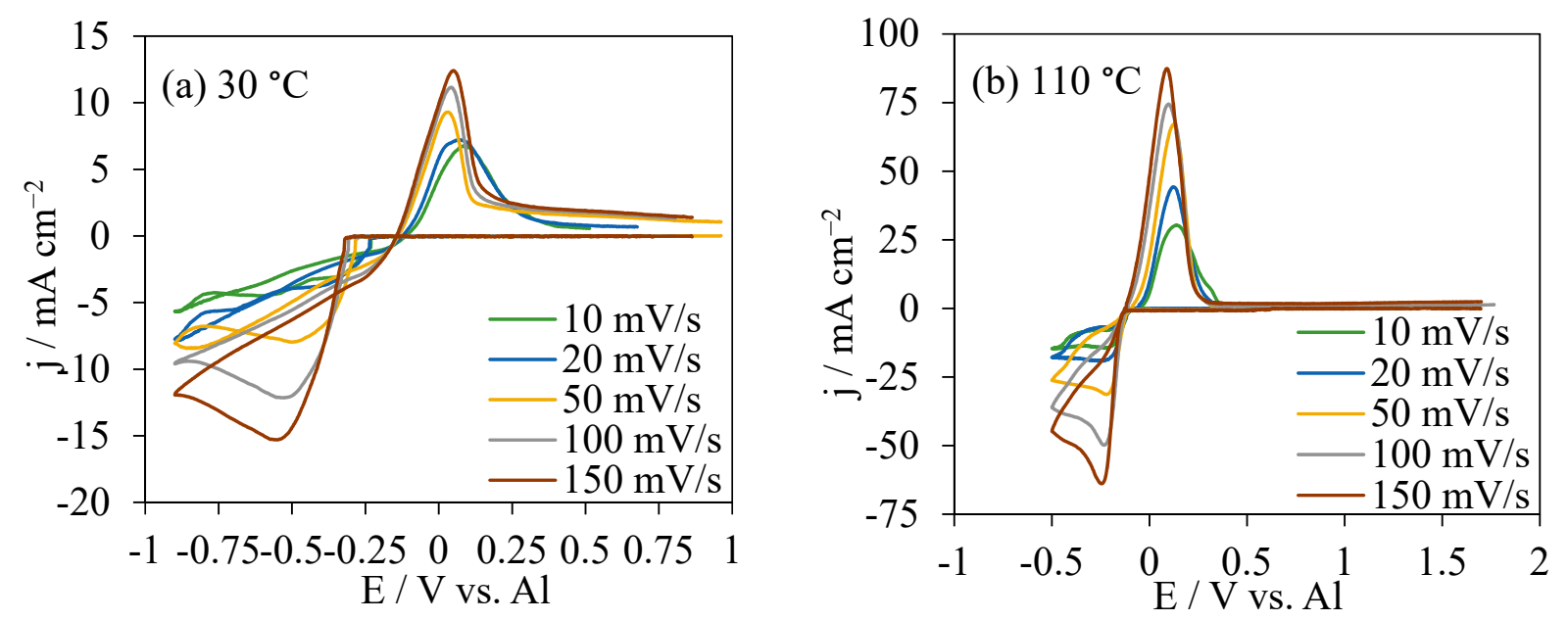

Figure 2. $\mathrm{CVs}$ at various scan rates in $\mathrm{AlCl}_{3} /[\mathrm{EMIm}] \mathrm{AlCl}_{4}(1: 5)$ at $30^{\circ} \mathrm{C}(\mathbf{a})$ and $110^{\circ} \mathrm{C}(\mathbf{b})$.

For $\mathrm{AlCl}_{3} /[\mathrm{EMIm}] \mathrm{AlCl}_{4}\left(1: 5, \chi_{\mathrm{AlCl}_{3}}=0.55\right)$, the system is composed of similar aluminum ions at $30^{\circ} \mathrm{C}$ and $110{ }^{\circ} \mathrm{C}$ with $80.0 \mathrm{~mol} \%\left[\mathrm{AlCl}_{4}\right]^{-}$and $20.0 \mathrm{~mol} \%\left[\mathrm{Al}_{2} \mathrm{Cl}_{7}\right]^{-}$at $30{ }^{\circ} \mathrm{C}$ while $80.2 \mathrm{~mol} \%\left[\mathrm{AlCl}_{4}\right]^{-}$and $19.8 \mathrm{~mol} \%\left[\mathrm{Al}_{2} \mathrm{Cl}_{7}\right]^{-}$at $110{ }^{\circ} \mathrm{C}$ (Figure 3). In the system, $\left[\mathrm{AlCl}_{4}\right]^{-}$, as the major component, could not be reduced to Al. Moreover, the minor component $\left[\mathrm{Al}_{2} \mathrm{Cl}_{7}\right]^{-}$was the active species for $\mathrm{Al}$ deposition [47-50]. During the electrolysis, $\left[\mathrm{Al}_{2} \mathrm{Cl}_{7}\right]^{-}$was reduced to aluminum metal and the generated $\left[\mathrm{AlCl}_{4}\right]^{-}$migrating to the anode (Equation (9)) [51,52].

$$
4\left[\mathrm{Al}_{2} \mathrm{Cl}_{7}\right]^{-}+3 e^{-} \rightarrow \mathrm{Al}+7\left[\mathrm{AlCl}_{4}\right]^{-}
$$



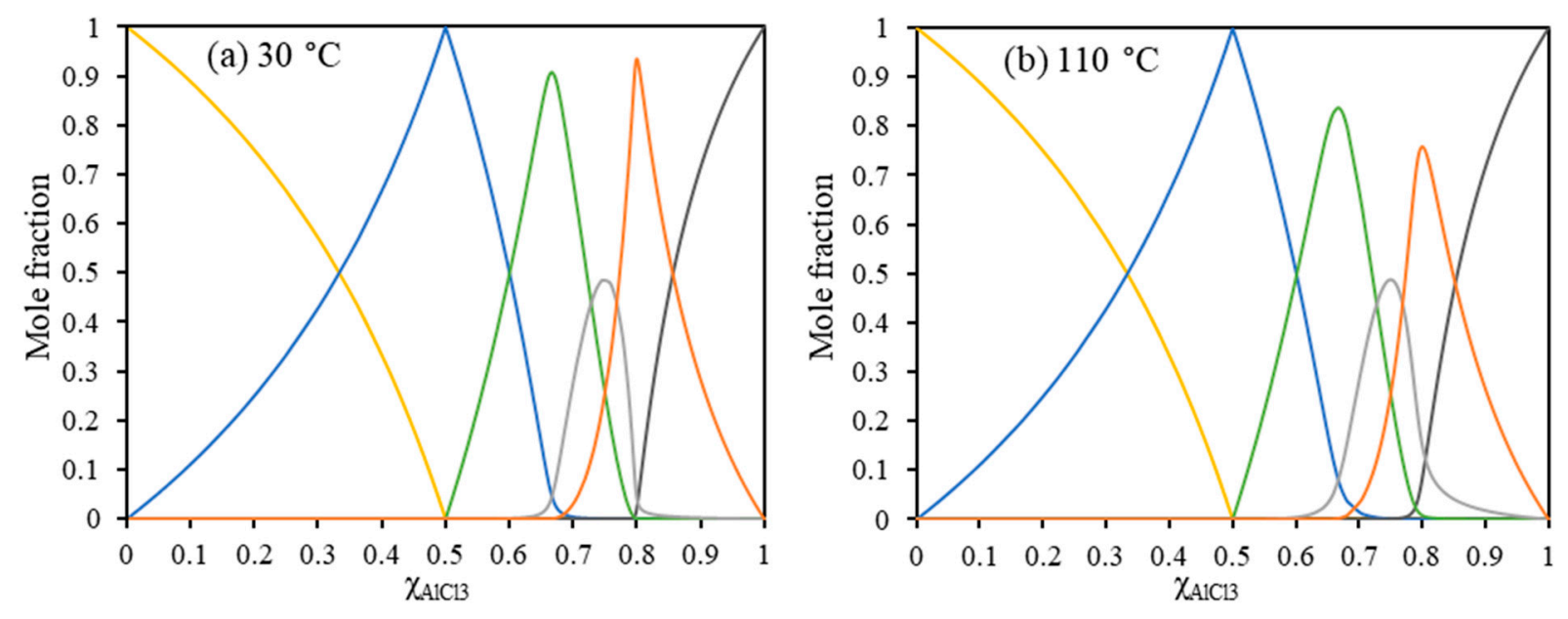

$-\mathrm{Cl}^{-} ;-\left[\mathrm{AlCl}_{4}\right]^{-} ;-\left[\mathrm{Al}_{2} \mathrm{Cl}_{7}\right]^{-} ;-\left[\mathrm{Al}_{3} \mathrm{Cl}_{10}\right]^{-} ;-\left[\mathrm{Al}_{4} \mathrm{Cl}_{13}\right]^{-} ;-\mathrm{Al}_{2} \mathrm{Cl}_{6} ;$

Figure 3. Calculated $\mathrm{Al}$ anion concentrations as a function of $\mathrm{X}_{\mathrm{AlCl}_{3}}$ at $30^{\circ} \mathrm{C}$ (a) and $110^{\circ} \mathrm{C} \mathrm{(b)}$.

The CVs in $\mathrm{AlCl}_{3} /[\mathrm{EMIm}] \mathrm{AlCl}_{4}$ (1:5) (Figure 2) at both temperatures exhibited the cathodic and anodic peaks potentials were more separated at higher scan rates. The separations of the Al reduction and re-oxidation peaks were more than $330 \mathrm{mV}$, which was larger than the critical peak splitting of $282 \mathrm{mV}\left(\frac{212}{n} \mathrm{mV}, n\right.$ is the number of electrons involved in the charge-transfer step, $n=0.75)[53,54]$, suggesting an irreversible system.

For an irreversible electrode reaction, the rate constant $\left(k^{0}\right)$ for the $\mathrm{Al}$ deposition was estimated from the shift of the cathodic peak potential $\left(E_{p c}\right)$ with the scan rates in CVs, based on Equation (10) [55]:

$$
E_{p c}=E^{0}-\frac{R T}{\alpha n_{a} F}\left[0.78-\ln \frac{k^{0}}{D^{1 / 2}}+\ln \left(\frac{\alpha n_{a} F v}{R T}\right)^{1 / 2}\right]
$$

where $E^{0}$ is the standard potential ( $E^{0}=0$ for the current system), $F$ is the Faraday's constant $96,485 \mathrm{C} \mathrm{mol}^{-1}, R$ is the gas constant $8.314 \mathrm{~J} \mathrm{~mol}^{-1} \mathrm{~K}^{-1}, D$ is the diffusion coefficient of active species $\left[\mathrm{Al}_{2} \mathrm{Cl}_{7}\right]^{-}$, and $\alpha$ is the transfer coefficient. Figure 4a showed linear relations of $E_{p c}$ and $l n v^{1 / 2}$. The values of $\alpha n_{a}$ could be derived from the slopes of lines at different temperatures, which were 0.38 and 0.74 for reactions at $30^{\circ} \mathrm{C}$ and $110{ }^{\circ} \mathrm{C}$, respectively. The diffusion coefficients were calculated from the Randles-Sevcik equation, based on the relationship between the cathodic peak current densities $\left(j_{p c}\right)$ correlating with scan rate $(v)$ for an irreversible system in Equation (11) [56]:

$$
j_{p c}=0.4958 \times n F C D^{1 / 2}\left(\frac{\alpha n_{a} F}{R T}\right)^{1 / 2} v^{1 / 2}
$$

where $C$ is the concentration of active species $\left[\mathrm{Al}_{2} \mathrm{Cl}_{7}\right]^{-}$and $n$ is the number of electrons involved in the charge-transfer step, $n=0.75$. The cathodic peak current densities and the square root of scan rate showed good linearity at $30^{\circ} \mathrm{C}$ and $110{ }^{\circ} \mathrm{C}$ (Figure $4 \mathrm{~b}$ ), indicating that the cathodic reaction was diffusion-controlled. The values of $D$ were estimated to be $9.71 \times 10^{-8} \mathrm{~cm}^{2} \mathrm{~s}^{-1}$ at $30{ }^{\circ} \mathrm{C}$ and $1.04 \times 10^{-6} \mathrm{~cm}^{2} \mathrm{~s}^{-1}$ at $110{ }^{\circ} \mathrm{C}$. In the literature, Lai et al. reported the $\alpha n_{a}$ at 0.44 and the diffusion coefficient of $\left[\mathrm{Al}_{2} \mathrm{Cl}_{7}\right]^{-}$was about $6.2 \times 10^{-8} \mathrm{~cm}^{2} \mathrm{~s}^{-1}$ at $40{ }^{\circ} \mathrm{C}$ in $\mathrm{AlCl}_{3} /[\mathrm{EMIm}] \mathrm{Cl}$ with $0.47 \mathrm{~mol} \mathrm{~L}^{-1}$ of $\left[\mathrm{Al}_{2} \mathrm{Cl}_{7}\right]^{-}$[50]. Based on the intercept in Figure $4 \mathrm{a}$, the values of the cathodic reduction rate constant were determined as $1.18 \times 10^{-5} \mathrm{~cm} \mathrm{~s}^{-1}$ and $3.37 \times 10^{-4} \mathrm{~cm} \mathrm{~s}^{-1}$ at $30^{\circ} \mathrm{C}$ and $110^{\circ} \mathrm{C}$, respectively. 

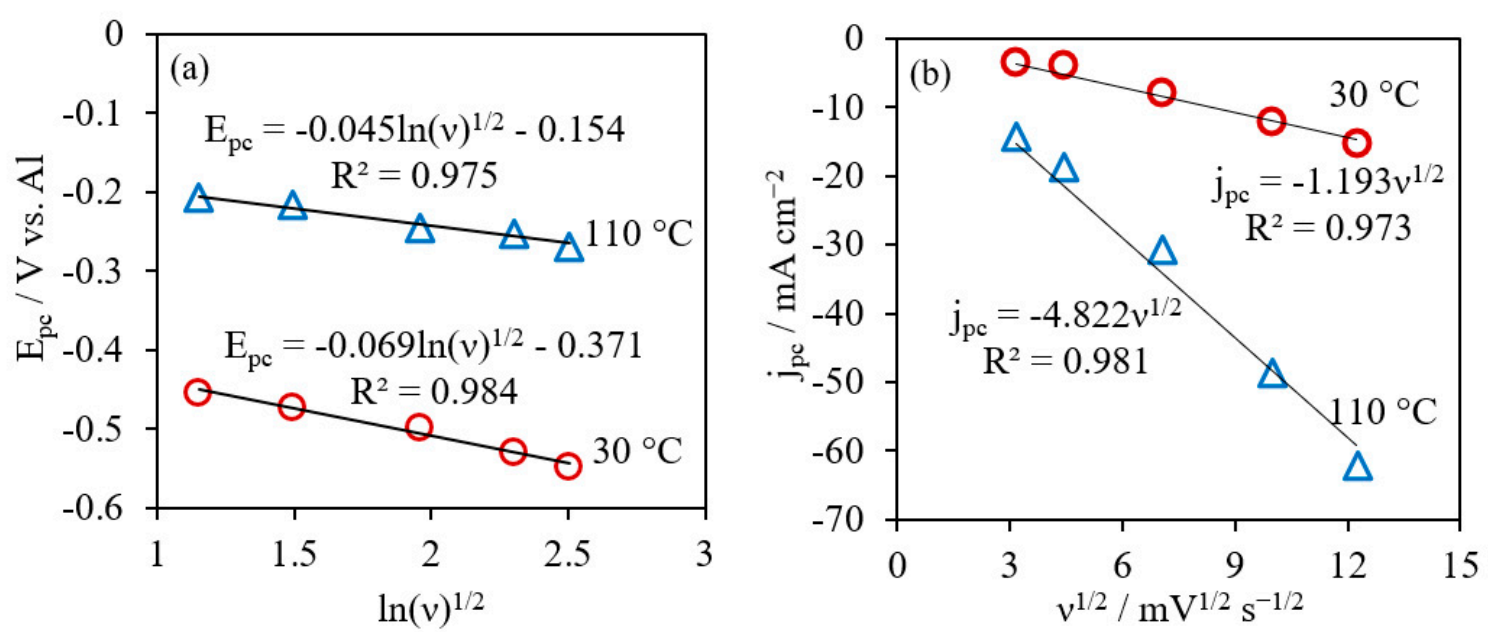

Figure 4. Plots of cathodic peak potential $E_{p}$ vs. $\ln (v)^{1 / 2}(\mathbf{a})$ and plots of cathodic peak current jpc as a function of $v^{1 / 2}(\mathbf{b})$ for $\mathrm{AlCl}_{3} /[\mathrm{EMIm}] \mathrm{AlCl}_{4}(1: 5)$ at $30^{\circ} \mathrm{C}$ and $110{ }^{\circ} \mathrm{C}$.

The $\mathrm{Al}$ deposits and the nucleation mechanisms can be achieved from the chronoamperometry studies. Al deposition potentials at both $30^{\circ} \mathrm{C}$ and $110{ }^{\circ} \mathrm{C}$ were chosen as the values achieved at $200 \mathrm{mV} \mathrm{s}^{-1}$ in CVs. In this way, it guaranteed the constant potentials in CA measurements were higher than the $\mathrm{Al}$ deposition potentials. The current-time profiles showed an initial slight decrease in current density followed by a sharp increase and gradual decrease to a plateau (Figure $5 a, b$ ). The initial decrease was due to the charging of the double layer and a decayed current during the nucleation process $[50,57,58]$. The current increase was the result of independent nucleus size growing and consequently the increase of total electroactive $\mathrm{Al}$ surface area. The following current decrease was because of the overlap of the diffusion zone leading to the formation of one diffusion layer [50]. As the applied potential being more significant, the current density peak became sharper with higher intensity and reached a higher plateau.

Initial stages of metal deposition were usually associated with a three-dimensional (3D) nucleation. For the diffusion controlled 3D nucleation, the instantaneous and progressive nucleation mechanisms were normally expressed in Equations (12) and (13), respectively [59].

$$
\begin{gathered}
\left(\frac{j}{j_{m}}\right)^{2}=1.9542\left[\left(t-t_{0}\right) /\left(t_{m}-t_{0}\right)\right]^{-1}\left\{1-\exp \left[-1.2564\left(t-t_{0}\right) /\left(t_{m}-t_{0}\right)\right]\right\}^{2} \\
\left(\frac{j}{j_{m}}\right)^{2}=1.2254\left[\left(t-t_{0}\right) /\left(t_{m}-t_{0}\right)\right]^{-1}\left\{1-\exp \left[-2.3367\left(t-t_{0}\right)^{2} /\left(t_{m}-t_{0}\right)^{2}\right]\right\}^{2}
\end{gathered}
$$

where $j$ is the current density at time $t, t_{0}$ is the induction time, and $t_{m}$ is the time at the maximum current density $j_{m}$. Figure $5 \mathrm{c}$, d gives a graphic analysis of the Al nucleation mechanism with the data extracted from Figure $5 \mathrm{a}, \mathrm{b}$ for the Al deposition onto the GC electrode at $30^{\circ} \mathrm{C}$ and $110^{\circ} \mathrm{C}$, respectively. The theoretical model curves were generated from Equations (12) and (13). At $30^{\circ} \mathrm{C}$, the nucleation process correlated with the progressive nucleation mechanism in the initial stage. After reaching the maximum current, the deposition was close to the progressive nucleation curve, but the process may be affected by other factors. At $110^{\circ} \mathrm{C}$, the phenomenon was more complicated. It followed the progressive nucleation mechanism for a short time, but the data lines fell on progressive and instantaneous nucleation mechanisms, and in the region in between. This nucleation kinetic was different from literature results for the $\mathrm{Al}$ deposition from $\mathrm{AlCl}_{3} /[\mathrm{EMIm}] \mathrm{Cl}$ which exhibited a better fit with the 3D instantaneous nucleation [3,9]. It is possibly the results of electrode surface changes during the depositions. Initially, the electrode surface was flat and small. Next, the surface gradually grew to a hemispheric shape with 
a large surface area. The changes happened in such a short time that the mass transfer and nucleation kinetics were complicated and could not be simply explained with only one mechanism. In addition, the existence of side reactions during the nucleation, such as the reduction of moisture and oxygen dissolved in the ionic liquid mixture, made the electroplating processes more complicated [60]. Al-contained species would precipitate due to the hydrogen extraction in water electrolysis and oxidized by oxygen generated. Charges were consumed not only by the $\mathrm{Al}$ deposition from $\left[\mathrm{Al}_{4} \mathrm{Cl}_{7}\right]^{-}$, but also by the side reaction discussed above. Therefore, the process resulted in a lower current efficiency and aluminum extraction ratio.
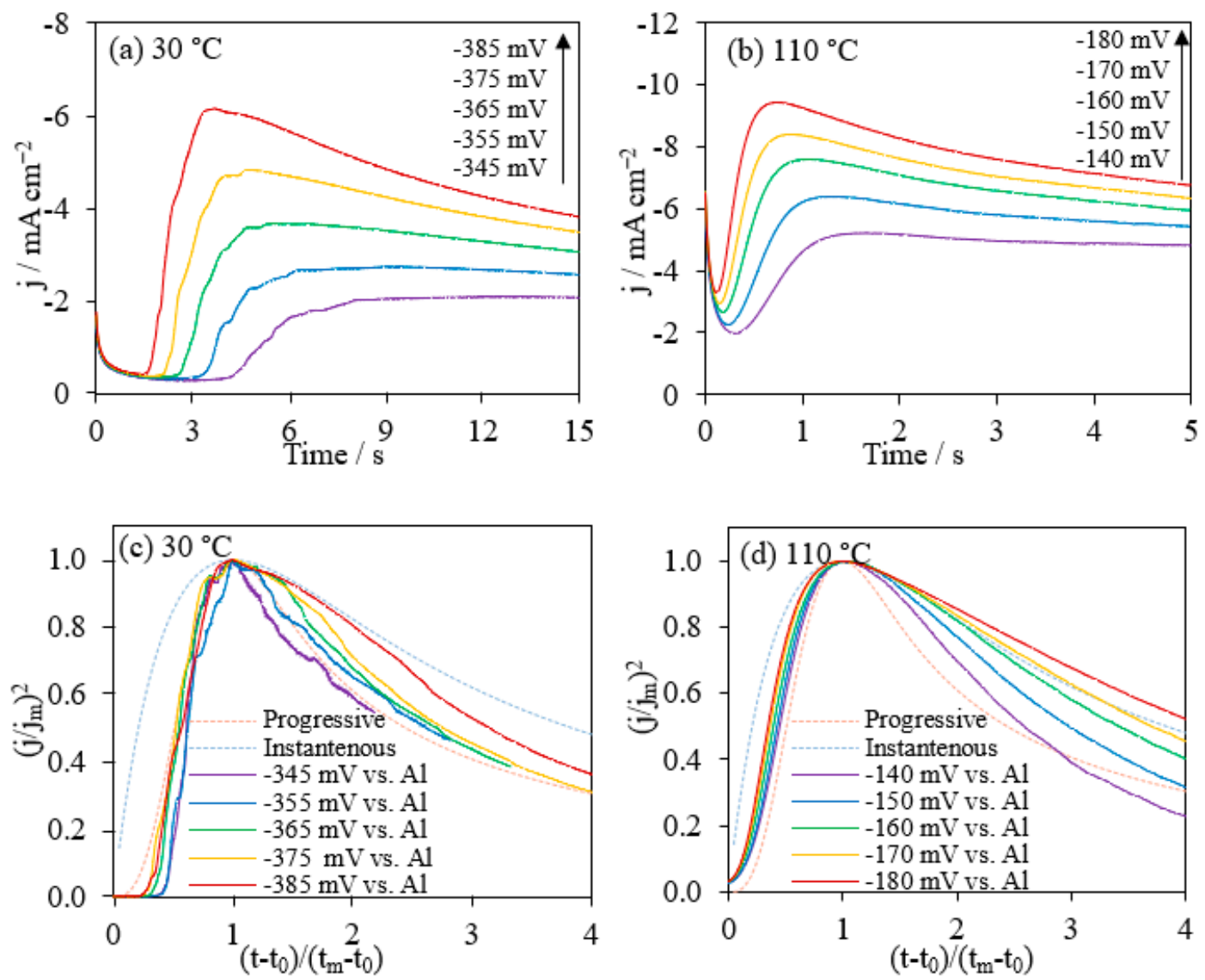

Figure 5. Current-time transients from potential step experiments on glassy carbon electrodes for $\mathrm{AlCl}_{3} /\left[\mathrm{EMIm} \mathrm{AlCl}_{4}\right.$ $(1: 5)$ at $30{ }^{\circ} \mathrm{C}(\mathbf{a})$ and $110^{\circ} \mathrm{C}(\mathbf{b})$. The comparison of the dimensionless experimental current-time transients $\left(j / j_{m}\right)^{2}$ vs. $(t-$ $\left.t_{0}\right) /\left(t_{m}-t_{0}\right)$ plots $(\mathbf{c}, \mathbf{d})$, which derived from subfigures $(\mathbf{a}, \mathbf{b})$, respectively, comparing with the theoretical models for the diffusion-controlled three-dimensional nucleation.

$\mathrm{Al}$ electrodepositions were studied at $110{ }^{\circ} \mathrm{C}$ on the glassy carbon substrates. Constant potentials were applied at the $\mathrm{Al}$ deposition potential defined with $\mathrm{CV}$ measurements. Figure $6 \mathrm{a}, \mathrm{b}$ shows the SEM images for two Al deposits under constant-potential polarization after the charge reached $2.9 \mathrm{C} \mathrm{cm}^{-2}$ and $14.5 \mathrm{C} \mathrm{cm}^{-2}$, respectively. The deposit with less charges exhibited both bright and black regions. Further growth of the deposit layer with more charges lead to the complete coating of the substrate, accompanied by the formation of minor cracks. The elemental analysis (Figure 6c) of the bright zone and the dark zone in Figure 6a confirmed that the polyhedral particles were $100 \% \mathrm{Al}$, and the black zone corresponded to the GC substrate. The XRD pattern of the $\mathrm{Al}$ layer deposited in Figure $6 \mathrm{~b}$ was shown in Figure 6d. The peaks were sharp and matched well with the standard Al (JCPDS 03-065-2869), indicative of a well-crystallized face-centered-cubic (fcc) structure based on the patterns in [111], [200], [220], [311] and [222]. The particle size for Al particles is estimated based on the Scherrer equation: $d=\frac{K \lambda}{\beta \cos \theta}$. $K$ is the shape factor at $0.9 ; \lambda$ is 
the $\mathrm{X}$-ray wavelength at $1.5406 A ; \beta$ is the line broadening at half the maximum intensity in radians, 0.008378; and $\theta$ is the Bragg angle. The size of $\mathrm{Al}$ particles was calculated at $8.77 \mathrm{~nm}$. Therefore, the result strongly supported the deposition of nano-size metallic $\mathrm{Al}$ during the cathode polarization.

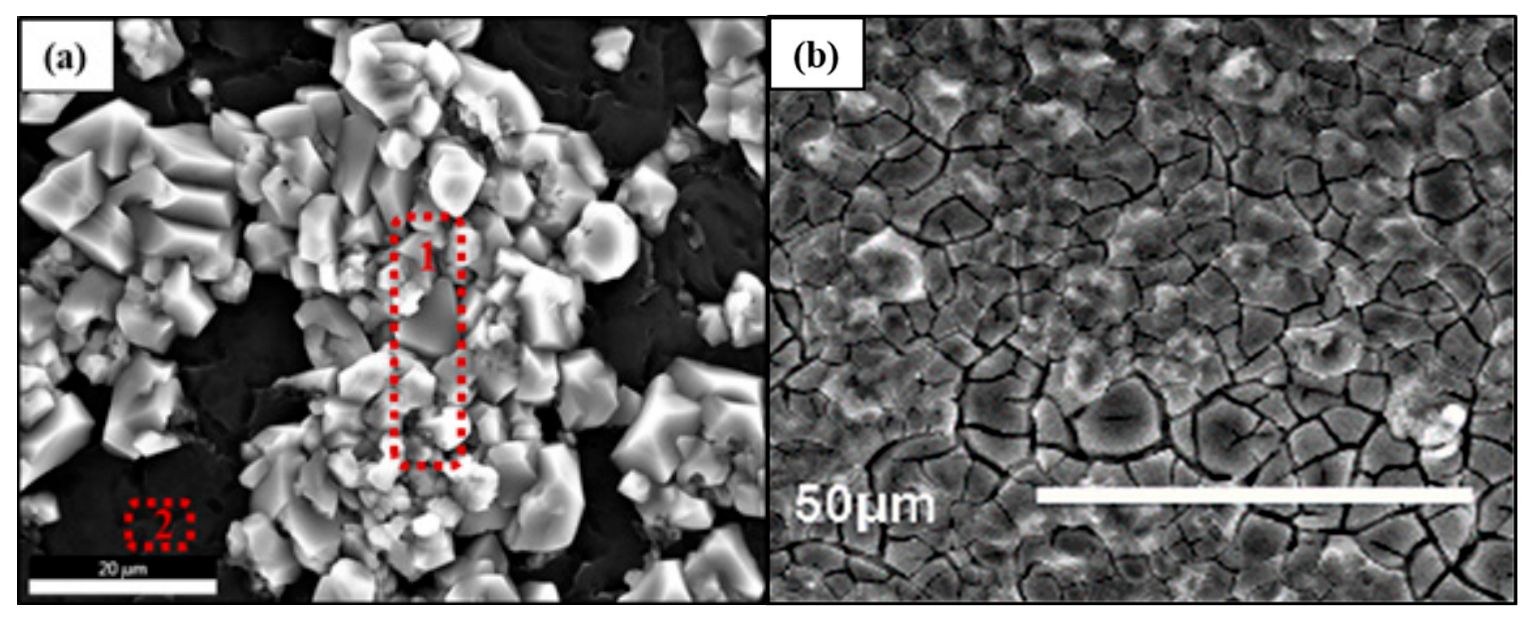

\begin{tabular}{|cccc|}
\hline (c) & & & \\
\hline Area & Element & Weight \% & Atomic\% \\
\hline 1 & $\mathrm{Al}$ & 100.00 & 100.00 \\
\hline & $\mathrm{C}$ & 99.65 & 99.86 \\
2 & $\mathrm{Al}$ & 0.25 & 0.11 \\
& $\mathrm{Cl}$ & 0.10 & 0.03 \\
\hline
\end{tabular}

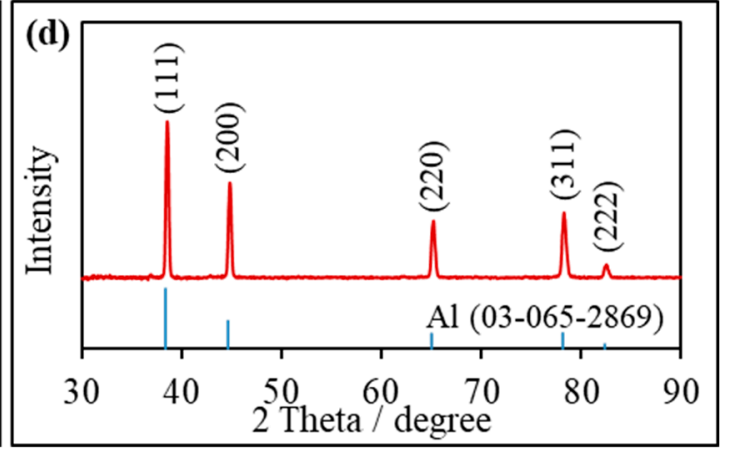

Figure 6. (a,b) SEM images of $\mathrm{Al}$ deposits $110{ }^{\circ} \mathrm{C}$ on the glassy carbon electrodes in the $\mathrm{AlCl}_{3} /\left[\mathrm{EMIm} \mathrm{AlCl}_{4}\right.$ ionic liquids with charges of 2.9 and $14.5 \mathrm{C} \mathrm{cm}^{-2}$, respectively; (c) EDS analysis of the Al deposit in panel (a); and (d) XRD pattern of an Al deposit in panel (b).

\section{Conclusions}

In this work, we explored the potential of the [EMIm] $\mathrm{AlCl}_{4}$ as the ionic liquid electrolyte and $\mathrm{AlCl}_{3}$ as the precursor for the electrodeposition of $\mathrm{Al}$. Because of its wide electrochemical window and low melting point, the [EMIm] $\mathrm{AlCl}_{4}$ is a prospective ionic liquid for the electrodeposition of Al. Thermodynamic models were established to show the composition of $\mathrm{Al}$ anions in $\mathrm{AlCl}_{3} / \mathrm{IL}$ mixtures at $30^{\circ} \mathrm{C}$ and $110{ }^{\circ} \mathrm{C}$. It was demonstrated that nano-sized $\mathrm{Al}$ was successfully deposited on glassy carbon after $\mathrm{AlCl}_{3}$ was added to the tetrachloroaluminate. The results from this work prove that the $\mathrm{AlCl}_{3} /[\mathrm{EMIm}] \mathrm{AlCl}_{4}$ mixture is a promising electrodeposition both in developing the process chemistry and improving the control of $\mathrm{Al}$ coating.

Author Contributions: Conceptualization, J.J.; methodology, M.S., J.J. and H.Z.; software, M.S.; validation, J.J. and H.Z.; formal analysis, M.S.; resources, J.J.; data curation, M.S.; writing-original draft preparation, M.S. and J.J.; writing—review and editing, H.Z.; project administration, J.J.; funding acquisition, J.J. All authors have read and agreed to the published version of the manuscript.

Funding: The work is supported through the INL Laboratory Directed Research \& Development (LDRD) Program under DOE Idaho Operations Office Contract DE-AC07-05ID14517. Publication of this article was funded by the University of Idaho-Open Access Publishing Fund.

Institutional Review Board Statement: Not applicable. 
Informed Consent Statement: Not applicable.

Data Availability Statement: No data is available for report.

Acknowledgments: This work is supported through the INL Laboratory Directed Research \& Development (LDRD) Program under DOE Idaho Operations Office Contract DE-AC07-05ID14517. The authors thank Jatuporn Burns at the Center for Advanced Energy Studies for performing SEM/EDS and XRD measurements, and assisting data analysis. Publication of this article was funded by the University of Idaho-Open Access Publishing Fund.

Conflicts of Interest: The authors declare no conflict of interest.

\section{References}

1. Zhao, Y.; VanderNoot, T.J. Electrodeposition of Aluminium from Nonaqueous Organic Electrolytic Systems and Room Temperature Molten Salts. Electrochim. Acta 1997, 42, 3-13. [CrossRef]

2. Tsuda, T.; Stafford, G.R.; Hussey, C.L. Review-Electrochemical Surface Finishing and Energy Storage Technology with RoomTemperature Haloaluminate Ionic Liquids and Mixtures. J. Electrochem. Soc. 2017, 164, H5007-H5017. [CrossRef]

3. Jiang, T.; Chollier Brym, M.J.; Dubé, G.; Lasia, A.; Brisard, G.M. Electrodeposition of Aluminium from Ionic Liquids: Part I-Electrodeposition and Surface Morphology of Aluminium from Aluminium Chloride ( $\left.\mathrm{AlCl}_{3}\right)-1$-Ethyl-3-Methylimidazolium Chloride ([EMIm]Cl) Ionic Liquids. Surf. Coat. Technol. 2006, 201, 1-9. [CrossRef]

4. Abbott, A.P.; Qiu, F.; Abood, H.M.A.; Ali, M.R.; Ryder, K.S. Double Layer, Diluent and Anode Effects upon the Electrodeposition of Aluminium from Chloroaluminate Based Ionic Liquids. Phys. Chem. Chem. Phys. 2010, 12, 1862-1872. [CrossRef] [PubMed]

5. Endres, F.; Bukowski, M.; Hempelmann, R.; Natter, H. Electrodeposition of Nanocrystalline Metals and Alloys from Ionic Liquids. Angew. Chem. Int. Ed. 2003, 42, 3428-3430. [CrossRef]

6. Hurley, F.H.; WIer, T.P. The Electrodeposition of Aluminum from Nonaqueous Solutions at Room Temperature. J. Electrochem. Soc. 1951, 98, 207-212. [CrossRef]

7. Zhang, Q.; Wang, Q.; Zhang, S.; Lu, X. Effect of Nicotinamide on Electrodeposition of $\mathrm{Al}$ from Aluminium $\left.\mathrm{Chloride} \mathrm{(AlCl}_{3}\right)-1-$ Butyl-3-Methylimidazolium Chloride ([Bmim]Cl) Ionic Liquids. J. Solid State Electrochem. 2014, 18, 257-267. [CrossRef]

8. Berretti, E.; Giaccherini, A.; Martinuzzi, S.M.; Innocenti, M.; Schubert, T.J.S.; Stiemke, F.M.; Caporali, S. Aluminium Electrodeposition from Ionic Liquid: Effect of Deposition Temperature and Sonication. Materials 2016, 9, 719. [CrossRef]

9. Tu, X.; Zhang, J.; Zhang, M.; Cai, Y.; Lang, H.; Tian, G.; Wang, Y. Electrodeposition of Aluminium Foils on Carbon Electrodes in Low Temperature Ionic Liquid. RSC Adv. 2017, 7, 14790-14796. [CrossRef]

10. Stafford, G.R.; Tsuda, T.; Hussey, C.L. The Structure of Electrodeposited Aluminum Alloys from Chloroaluminate Ionic Liquids: Let's Not Ignore the Temperature. ECS Meet. Abstr. 2014, MA2014-02, 1484. [CrossRef]

11. Tang, J.; Azumi, K. Improvement of Al Coating Adhesive Strength on the AZ91D Magnesium Alloy Electrodeposited from Ionic Liquid. Surf. Coat. Technol. 2012, 208, 1-6. [CrossRef]

12. Schaltin, S.; Ganapathi, M.; Binnemans, K.; Fransaer, J. Modeling of Aluminium Deposition from Chloroaluminate Ionic Liquids. J. Electrochem. Soc. 2011, 158, D634-D639. [CrossRef]

13. Wang, Q.; Zhang, Q.; Chen, B.; Lu, X.; Zhang, S. Electrodeposition of Bright Al Coatings from 1-Butyl-3-Methylimidazolium Chloroaluminate Ionic Liquids with Specific Additives. J. Electrochem. Soc. 2015, 162, D320-D324. [CrossRef]

14. Abdul-Sada, A.K.; Greenway, A.M.; Seddon, K.R.; Welton, T. A Fast Atom Bombardment Mass Spectrometric Study of RoomTemperature 1-Ethyl-3-Methylimidazolium Chloroaluminate(III) Ionic Liquids. Evidence for the Existence of the Decachlorotrialuminate(III) Anion. Org. Mass Spectrom. 1993, 28, 759-765. [CrossRef]

15. Franzen, G.; Gilbert, B.P.; Pelzer, G.; DePauw, E. The Anionic Structure of Room-Temperature Organic Chloroaluminate Melts from Secondary Ion Mass Spectrometry. Org. Mass Spectrom. 1986, 21, 443-444. [CrossRef]

16. Brown, L.C.; Hogg, J.M.; Swadźba-Kwaśny, M. Lewis Acidic Ionic Liquids. In Ionic Liquids II; Kirchner, B., Perlt, E., Eds.; Springer International Publishing: Cham, Switzerland, 2018; pp. 185-224. ISBN 978-3-319-89794-3.

17. Al Farisi, S.M.; Hertel, S.; Wiemer, M.; Otto, T. Aluminum Patterned Electroplating from $\mathrm{AlCl}_{3}$-[EMIm]Cl Ionic Liquid towards Microsystems Application. Micromachines 2018, 9, 589. [CrossRef]

18. Fannin, A.A.; King, L.A.; Levisky, J.A.; Wilkes, J.S. Properties of 1,3-Dialkylimidazolium Chloride-Aluminum Chloride Ionic Liquids. 1. Ion Interactions by Nuclear Magnetic Resonance Spectroscopy. J. Phys. Chem. 1984, 88, 2609-2614. [CrossRef]

19. Dymek, C.J.; Hussey, C.L.; Wilkes, J.S.; Øye, H.A. Thermodynamics of 1-Methyl-3-Ethylimidazolium Chloride-Aluminum Chloride Mixtures. ECS Proc. Vol. 1987, 7, 93-104. [CrossRef]

20. Øye, H.A.; Jagtoyen, M.; Oksefjell, T.; Wilkes, J.S. Vapour Pressure and Thermodynamics of the System 1-Methyl-3-EthylImidazolium Chloride-Aluminium Chloride. Mater. Sci. Forum 1991, 73-75, 183-190. [CrossRef]

21. Zhang, M.; Kamavarum, V.; Reddy, R.G. New Electrolytes for Aluminum Production: Ionic Liquids. J. Miner. Met. Mater. Soc. 2003, 55, 54-57. [CrossRef]

22. Wilkes, J.S.; Levisky, J.A.; Wilson, R.A.; Hussey, C.L. Dialkylimidazolium Chloroaluminate Melts: A New Class of RoomTemperature Ionic Liquids for Electrochemistry, Spectroscopy and Synthesis. Inorg. Chem. 1982, 21, 1263-1264. [CrossRef] 
23. Hussey, C.L.; Scheffler, T.B.; Wilkes, J.S.; Fannin, A.A. Chloroaluminate Equilibria in the Aluminum Chloride-1-Methyl-3ethylimidazolium Chloride Ionic Liquid. J. Electrochem. Soc. 1986, 133, 1389-1391. [CrossRef]

24. Karpinski, Z.J.; Osteryoung, R.A. Determination of Equilibrium Constants for the Tetrachloroaluminate Ion Dissociation in Ambient-Temperature Ionic Liquids. Inorg. Chem. 1984, 23, 1491-1494. [CrossRef]

25. Fannin, A.A.; Floreani, D.A.; King, L.A.; Landers, J.S.; Piersma, B.J.; Stech, D.J.; Vaughn, R.L.; Wilkes, J.S.; Williams, J.L. Properties of 1,3-Dialkylimidazolium Chloride-Aluminum Chloride Ionic Liquids. 2. Phase Transitions, Densities, Electrical Conductivities, and Viscosities. J. Phys. Chem. 1984, 88, 2614-2621. [CrossRef]

26. Bakkar, A.; Neubert, V. A New Method for Practical Electrodeposition of Aluminium from Ionic Liquids. Electrochem. Commun. 2015, 51, 113-116. [CrossRef]

27. Pradhan, D.; Reddy, R.G. Mechanistic Study of Al Electrodeposition from EMIC- $\mathrm{AlCl}_{3}$ and BMIC-AlCl ${ }_{3}$ Electrolytes at Low Temperature. Mater. Chem. Phys. 2014, 143, 564-569. [CrossRef]

28. Hou, Y.; Li, R.; Liang, J. Simultaneous Electropolishing and Electrodeposition of Aluminum in Ionic Liquid under Ambient Conditions. Appl. Surf. Sci. 2018, 434, 918-921. [CrossRef]

29. Bakkar, A.; Neubert, V. Electrodeposition and Corrosion Characterisation of Micro- and Nano-Crystalline Aluminium from $\mathrm{AlCl}_{3}$ /1-Ethyl-3-Methylimidazolium Chloride Ionic Liquid. Electrochim. Acta 2013, 103, 211-218. [CrossRef]

30. Pulletikurthi, G.; Bödecker, B.; Borodin, A.; Weidenfeller, B.; Endres, F. Electrodeposition of Al from a 1-Butylpyrrolidine$\mathrm{AlCl}_{3}$ Ionic Liquid. Prog. Nat. Sci. Mater. Int. 2015, 25, 603-611. [CrossRef]

31. Nara, S.J.; Harjani, J.R.; Salunkhe, M.M. Friedel—Crafts Sulfonylation in 1-Butyl-3-Methylimidazolium Chloroaluminate Ionic Liquids. J. Org. Chem. 2001, 66, 8616-8620. [CrossRef]

32. Zein El Abedin, S.; Giridhar, P.; Schwab, P.; Endres, F. Electrodeposition of Nanocrystalline Aluminium from a Chloroaluminate Ionic Liquid. Electrochem. Commun. 2010, 12, 1084-1086. [CrossRef]

33. Elia, G.A.; Kravchyk, K.V.; Kovalenko, M.V.; Chacón, J.; Holland, A.; Wills, R.G.A. An Overview and Prospective on Al and Al-Ion Battery Technologies. J. Power Sources 2021, 481, 228870. [CrossRef]

34. Elia, G.A.; Greco, G.; Kamm, P.H.; García-Moreno, F.; Raoux, S.; Hahn, R. Simultaneous X-Ray Diffraction and Tomography Operando Investigation of Aluminum/Graphite Batteries. Adv. Funct. Mater. 2020, 30, 2003913. [CrossRef]

35. Zhao, Q.; Zachman, M.J.; Al Sadat, W.I.; Zheng, J.; Kourkoutis, L.F.; Archer, L. Solid Electrolyte Interphases for High-Energy Aqueous Aluminum Electrochemical Cells. Sci. Adv. 2018, 4, eaau8131. [CrossRef] [PubMed]

36. He, S.; Wang, J.; Zhang, X.; Chen, J.; Wang, Z.; Yang, T.; Liu, Z.; Liang, Y.; Wang, B.; Liu, S.; et al. A High-Energy Aqueous Aluminum-Manganese Battery. Adv. Funct. Mater. 2019, 29, 1905228. [CrossRef]

37. Wu, C.; Gu, S.; Zhang, Q.; Bai, Y.; Li, M.; Yuan, Y.; Wang, H.; Liu, X.; Yuan, Y.; Zhu, N.; et al. Electrochemically Activated Spinel Manganese Oxide for Rechargeable Aqueous Aluminum Battery. Nat. Commun. 2019, 10, 73. [CrossRef]

38. de Andrade, J.; Böes, E.S.; Stassen, H. A Force Field for Liquid State Simulations on Room Temperature Molten Salts: 1-Ethyl-3Methylimidazolium Tetrachloroaluminate. J. Phys. Chem. B 2002, 106, 3546-3548. [CrossRef]

39. de Andrade, J.; Böes, E.S.; Stassen, H. Alkyl Chain Size Effects on Liquid Phase Properties of 1-Alkyl-3-Methylimidazolium Tetrachloroaluminate Ionic Liquids-A Microscopic Point of View from Computational Chemistry. J. Phys. Chem. B 2009, 113, 7541-7547. [CrossRef]

40. Øye, H.A.; Rytter, E.; Klæboe, P.; Cyvin, S.J. Raman Spectra of $\mathrm{KCl}-\mathrm{AlCl}_{3} \mathrm{Melts}$ and Normal Coordinate Analysis of $\mathrm{Al}_{2} \mathrm{C}_{17^{-}}$. Acta Chem. Scand. 1971, 25, 559-576. [CrossRef]

41. Lockett, V.; Sedev, R.; Ralston, J.; Horne, M.; Rodopoulos, T. Differential Capacitance of the Electrical Double Layer in ImidazoliumBased Ionic Liquids: Influence of Potential, Cation Size, and Temperature. J. Phys. Chem. C 2008, 112, 7486-7495. [CrossRef]

42. Vaughan, J.; Dreisinger, D. Potentiodynamic Polarization of Platinum and Aluminum in $\mathrm{AlCl}_{3}-[\mathrm{P} 14,6,6,6] \mathrm{Cl}$ Melts. ECS Trans. 2009, 16, 397-409. [CrossRef]

43. Suarez, P.A.Z.; Selbach, V.M.; Dullius, J.E.L.; Einloft, S.; Piatnicki, C.M.S.; Azambuja, D.S.; de Souza, R.F.; Dupont, J. Enlarged Electrochemical Window in Dialkyl-Imidazolium Cation Based Room-Temperature Air and Water-Stable Molten Salts. Electrochim. Acta 1997, 42, 2533-2535. [CrossRef]

44. Gordon, C.M.; Muldoon, M.J.; Wagner, M.; Hilgers, C.; Davis, J.H., Jr.; Wasserscheid, P. Synthesis and Purification. In Ionic Liquids in Synthesis; John Wiley \& Sons, Ltd.: Hoboken, NJ, USA, 2008; pp. 7-55. ISBN 978-3-527-62119-4.

45. Nelson, W.M. Green Solvents for Chemistry: Perspectives and Practice; Oxford University Press: Oxford, UK, 2003; ISBN 0-19-803576-4.

46. Koronaios, P.; King, D.; Osteryoung, R.A. Acidity of Neutral Buffered 1-Ethyl-3-Methylimidazolium $\mathrm{Chloride}-\mathrm{AlCl}_{3} \mathrm{Ambient}^{-}$ Temperature Molten Salts. Inorg. Chem. 1998, 37, 2028-2032. [CrossRef]

47. Dymek, C.J.; Williams, J.L.; Groeger, D.J.; Auborn, J.J. An Aluminum Acid-Base Concentration Cell Using Room Temperature Chloroaluminate Ionic Liquids. J. Electrochem. Soc. 1984, 131, 2887-2892. [CrossRef]

48. MacFarlane, D.R.; Kar, M.; Pringle, J.M. Synthesis of Ionic Liquids. In Fundamentals of Ionic Liquids; John Wiley \& Sons, Ltd.: Hoboken, NJ, USA, 2017; pp. 81-102. ISBN 978-3-527-34003-3.

49. Ismail, A.S. Nano-Sized Aluminum Coatings from Aryl-Substituted Imidazolium Cation Based Ionic Liquid. Egypt. J. Pet. 2016, 25, 525-530. [CrossRef]

50. Lai, P.K.; Skyllas-Kazacos, M. Electrodeposition of Aluminium in Aluminium Chloride/1-Methyl-3-Ethylimidazolium Chloride. J. Electroanal. Chem. Interfacial Electrochem. 1988, 248, 431-440. [CrossRef] 
51. Zhu, G.; Angell, M.; Pan, C.-J.; Lin, M.-C.; Chen, H.; Huang, C.-J.; Lin, J.; Achazi, A.J.; Kaghazchi, P.; Hwang, B.-J.; et al. Rechargeable Aluminum Batteries: Effects of Cations in Ionic Liquid Electrolytes. RSC Adv. 2019, 9, 11322-11330. [CrossRef]

52. Lin, M.-C.; Gong, M.; Lu, B.; Wu, Y.; Wang, D.-Y.; Guan, M.; Angell, M.; Chen, C.; Yang, J.; Hwang, B.-J.; et al. An Ultrafast Rechargeable Aluminium-Ion Battery. Nature 2015, 520, 324-328. [CrossRef]

53. Nicholson, R.S. Theory and Application of Cyclic Voltammetry for Measurement of Electrode Reaction Kinetics. Anal. Chem. 1965, 37, 1351-1355. [CrossRef]

54. Paul, H.J.; Leddy, J. Direct Determination of the Transfer Coefficient from Cyclic Voltammetry: Isopoints as Diagnostics. Anal. Chem. 1995, 67, 1661-1668. [CrossRef]

55. Wang, J. Analytical Electrochemistry, 3rd ed.; Wiley: New York, NY, USA, 2006; ISBN 978-0-471-67879-3.

56. Brett, C.M.A.; Brett, A.M.O. Electrochemistry Principles, Methods, and Applications; Oxford University Press: Oxford, UK, 1993; ISBN 978-0-19-855388-5.

57. Marsden, K.C.; Pesic, B. Evaluation of the Electrochemical Behavior of CeCl3 in Molten LiCl-KCl Eutectic Utilizing Metallic Ce as an Anode. J. Electrochem. Soc. 2011, 158, F111. [CrossRef]

58. Serrano, K.; Taxil, P. Electrochemical Nucleation of Uranium in Molten Chlorides. J. Appl. Electrochem. 1999, 29, 505-510. [CrossRef]

59. Branco, P.D.; Mostany, J.; Borrás, C.; Scharifker, B.R. The Current Transient for Nucleation and Diffusion-Controlled Growth of Spherical Caps. J. Solid State Electrochem. 2009, 13, 565-571. [CrossRef]

60. Rodríguez-Clemente, E.; Manh, T.L.; Guinto-Pano, C.E.; Romero-Romo, M.; Mejía-Caballero, I.; Morales-Gil, P.; Palacios-González, E.; Ramírez-Silva, M.T.; Palomar-Pardavé, M. Aluminum Electrochemical Nucleation and Growth onto a Glassy Carbon Electrode from a Deep Eutectic Solvent. J. Electrochem. Soc. 2019, 166, D3035-D3041. [CrossRef] 